\title{
New laws divide lawmakers
}

\section{Washington}

US CONGRESSIONAL moves to increase penalties for animal-rights break-ins have run into opposition from the Justice Department.

Several congressional bills now under consideration make crimes by animal activists against research laboratories a federal offence, with harsh penalties and probable investigation by the Federal Bureau of Investigation (FBI).

But the Justice Department opposes the bills, not because of ideological disagreement over whether activist crimes should be pursued with more fervour, but because the Republican party objects to the transfer of power from the states to the federal government (see Nature 343, 580; 15 February 1990).

The White House Office of Science and Technology Policy (OSTP) is, however, strongly in support of the bills. In the letter sent to the House Agriculture Committee, which held hearings on the issue last week, OSTP director D. Allan Bromley and associate director for life science James Wyngaarden (the former director of the National Institutes of Health) said that they object to the Justice Department's policy and believe that the administration should support the legislation.

"The animal rights movement is a national movement, with considerable circumstantial evidence of conspiratorial behavior", the letter states. The letter advocates the use of the FBI to investigate "this growing, well-organized, wellfinanced, unscrupulous movement". It also notes that People for the Ethical Treatment of Animals (PETA), a prominent animal-rights organization, often has videotapes and issues press releases shortly after break-ins attributed to the Animal Liberation Front (ALF), an underground activist group.

PETA co-founder Alex Pacheco says his organization abhors violence. At a recent press conference, Pacheco confirmed that PETA can legally use material collected during ALF raids, but "we don't know who [the ALF members] are and we don't want to know", he said. Until legislation is passed to allow outside inspection of animal research laboratories, PETA would continue to use the ALF-supplied information in the same way as a journalist would use leaked information, he said.

In the latest incident, PETA last week confirmed that it had received copies of documents stolen by the ALF last month from the offices of Adrian Morrison, a University of Pennsylvania sleep researcher. Morrison has been the chairman of the society for Neurosciences' Committee on Animal Research since 1987, and is a vocal defender of animal research.

The differences in opinion between OSTP and the Justice Department over the best legislation measures to deal with laboratory break-ins are compounded by divisions within Congress itself, where there are now nearly 80 current bills that would create legislation either in support of or in opposition to animal-rights issues, according to the National Alliance for Animal Legislation (NAAL).

Fifty-seven of the active bills support an increase in animal rights, welfare or protection and have the support of NAAL. The other 21 bills propose additional BRAZIL

\section{Ecologist appointed to environment post}

\section{São Paulo}

IN a move designed to demonstrate to the world Brazil's concern for the environment, president-elect Fernando Collor de Mello has appointed the ecologist José Lutzenberger as head of a new National Secretariat for the Environment.

Lutzenberger is one of Brazil's best known and most vociferous environmentalists. He has been a critic of government subsidy schemes that have led to the destruction of rain forest by encouraging cattle ranching, and he opposes the extension of route BR-364 through Acre to Peru. When BR-364 was built into Rondonia, it provided access for huge numbers of set- protection or support for animal research facilities and support of other non-research issues such as hunting, trapping or fishing rights - positions NAAL opposes.

Eleven bills call for tighter regulations for animal-research laboratories, limitations on the use of genetically engineered animals and toxicology testing and greater authority for private citizens to sue on behalf of animals.

On the other side are seven bills that support animal research, from one that authorizes $\$ 25$ million to rebuild a mousebreeding laboratory that burned down last year, to those that offer more protection against animal-activist attacks.

\section{G. Christopher Anderson} NUCLEAR POWER

\section{Embattled Seabrook wins licence at last}

\section{Boston}

NEW Hampshire's Seabrook nuclear power plant, perhaps the most bitterly opposed reactor ever to be completed, received a full-power operating licence last week from the US Nuclear Regulatory Commission (NRC). The licence comes after more than a decade of opposition and delays during which time construction costs for the plant rose to $\$ 6,450$ million, more than ten times the original estimate.

Seabrook opponents, including leading legislators in the neighbouring state of Massachusetts, say they will appeal against the NRC decision in court. Calling the licensing decision "unconscionable", Massachusetts Governor Michael Dukakis says that his state will base part of its legal challenge upon the fact that the NRC changed its own rules on three separate occasions to allow the controversial plant to proceed.

Because of its chequered history, Massachusetts Attorney General James Shannon claims that Seabrook has the "most legally vulnerable license the NRC has ever issued". Nonetheless, both sides in the dispute acknowledge that there is tlers who rapidly turned the state into the most deforested region of the Amazon. With extension of the road, the same fate is likely for Acre.

Lutzenberger is also a defendant of debtfor-nature swaps and has attacked President José Sarney's refusal to link negotiation of foreign debt repayments and environmental protection measures. But it is not known if the new president will accept Lutzenberger's views on this issue.

The agency that Lutzenberger will head is a new one and will be created in a planned reform of the administration. Collor will assume power next week.

Ricardo Bonalume little precedent for court intervention at this stage of the licensing process. So most observers predict that the plant is likely to be operating at full power later this spring.

Utility representatives at the New England Power Pool, which manages the region's electric power grid, say Seabrook's additional 1,150 MW of electricity will help them to combat the power shortages that have forced frequent voltage reductions in the region over the past year. Most consumers, however, are wary of the increases in utility rates that are likely to be passed on to them once the plant is operating, increases that are estimated to add an additional \$24 annually to the bill of every electricity consumer in New England.

Utility and nuclear industry representatives rightly declare the licence a victory for the embattled Seabrook plant, but participants on both sides of the dispute agree that the construction and licensing process has been so gruelling and costly that it may discourage the nuclear industry for a long time to come.

Seth Shulman 